\title{
Dividend Policy and Value of Quoted Firms in Nigeria: A Test of Miller and Modigliani Irrelevant Hypothesis
}

\author{
Lucky Anyike Lucky \\ Department of Banking and Finance \\ Rivers State University, Port Harcourt, Nigeria \\ E-mail: lucky.anyike@yahoo.com \\ Uzokwe Grace Onyinyechi \\ Department of Banking and Finance \\ Rivers State University, Port Harcourt, Nigeria
}

\begin{abstract}
This study tested Miller and Modigliani dividend policy irrelevant hypothesis in Nigeria. The objective was to examine the validity of the irrelevant hypothesis. Tobins $Q$ measure of market value was modeled as the function of dividend payout ratio, retention ratio, dividend per share and dividend yield. 20 firms were selected on the basis of availability of information necessary for conducting the study and the readiness of annual financial reports for the period of 10 years from 2008-20I7. Cross sectional data was sourced from financial statement and annual reports of the firms. Based on the analysis of fixed and random effect results, random effect was used. The study revealed that 75 percent variation on the market value can be predicted by variation on independent variables in the regression model. The beta coefficient of the variables found that all the independent variables have positive and significant relationship with market value of the selected quoted firms. The study concludes that dividend policy is relevant as oppose to the irrelevant hypothesis of Miller and Modigliani. Its therefore recommend that managers should manage their dividend policies effectively since it is relevant and has significant effect on market value and optimal dividend policy which implies policy of trade-off between dividend payout and retain earnings should be well managed and investors should have adequate knowledge of dividend policy of quoted firms that will correspond with their investment objectives of avoid conflict in dividend policy.
\end{abstract}

Keywords: Dividend Policy, Value of Quoted Firms, Nigeria, Miller and Modigliani, Irrelevant Hypothesis.

\section{Introduction}

Dividend policy behavior assumes that the change in dividend can be explained by previous period dividends and target dividends, which can be expressed as a fraction of the profit for that period. Lintner (1956) first published a basic model of this type of dividend policy. His model is based on a series of interviews with executives about their dividend policy. According to Lintner's interviews, it was clear that the corporate dividend policy was not uniform. The complexity of dividend distribution has left many questions unanswered about the impact of dividends on company value and the conditions under which such effects are felt. In a company, management determines the amount or portion of profit to be distributed as dividends through its dividend policy and the amount withheld for internal operations. The post-tax profits of corporate organizations contribute to the source of dividend payments (Toby, 20I4). There are some areas of finance that have intrigued researchers. One is corporate dividend behavior. Along with its capital structure, dividend policy has been one of the first areas of corporate finance to be analyzed in a rigorous model, and has since been one of the most studied topics in modern finance.

Dividend policy evolved with prescribed legal framework. In Nigeria part XIII, Section 379 - 385 spell out the legal framework for dividend policy. "Section 38I of CAMA stated that company shall not declare or pay dividend if there are reasonable ground for believing the company would be unable to meet up with or pay its liabilities as they become due. Section 382 states that companies cannot pay dividend out of capital since it will lead to depletion of capital which is against the legal principle that the capital must maintain. The decision to pay dividend is important for firms as it may affect the financial structure and stock price of the firm" Pandy (2005). The classical opinion has been that dividend policy influenced share prices and market prices of an equity represents the present value of estimated cash dividend hat can be generated by the equity Gordon (I959), while Miller and Modiliglani (I96I) opined that stock prices is function of the earnings of the firm dividend policy is irrelevant.

The controversies on the effect of dividend policy on stock price have deepened on the stock market of the emerging economics such as Nigeria. The theoretical assumptions underlying the different argument are based on the stock market of the developed countries which is more efficient compared with the Nigerian capital market which is characterized with insider dealings and undefined regime. The market cannot be considered deregulated or regulated to determine the effect of dividend policy on stock prices. 
Dividend policy remains one of the most controversial issues in corporate finance. The relationship between dividend policy and stock prices of listed firms has remained very sharp point of departure among scholars in corporate finance. The intensity of the debate has remained largely unresolved in both the global and local arena. Empirical evidence has shown that dividend policy is relevant as formulated by Gordon.

The age-long debate on the relationship between dividend policy and stock prices or put differently, the value of the firm rages on and dates back to Walter and the "Bird in Hand" theory in 1928, Gordon (1960) and the dividend relevance hypotheses and Miller and Modigliani (1962) and the dividend irrelevance hypotheses which have presented a serious challenge to academia and practitioners alike. Prior academic literatures have attempted to provide answers to questions on dividend policy and harmonize the theories but mystery still shrouds the dividend policy decisions of corporate organizations in general and more on the emerging financial market like Nigeria. The "complexity of dividend issues has left many questions unanswered regarding the relationship between dividend policy and the stock price of the firms and the direction of impact. The opinion of this study based on theory is that dividend policy is relevant."

\section{Literature Review}

Theoretical Models of Dividend Policy

Walter's Model of Dividend Policy

"Walter argues that choosing a dividend policy almost always affects the value of the company. His model, one of the earliest theoretical works, demonstrates the importance of the relationship between the rate of return on a company and the cost of capital, $\mathrm{k}$, in determining a dividend policy that would increase shareholder wealth."

The model is specified as follows:

$$
P=\frac{D I V}{k}+\frac{r(E P S-D I V) / k}{k}
$$
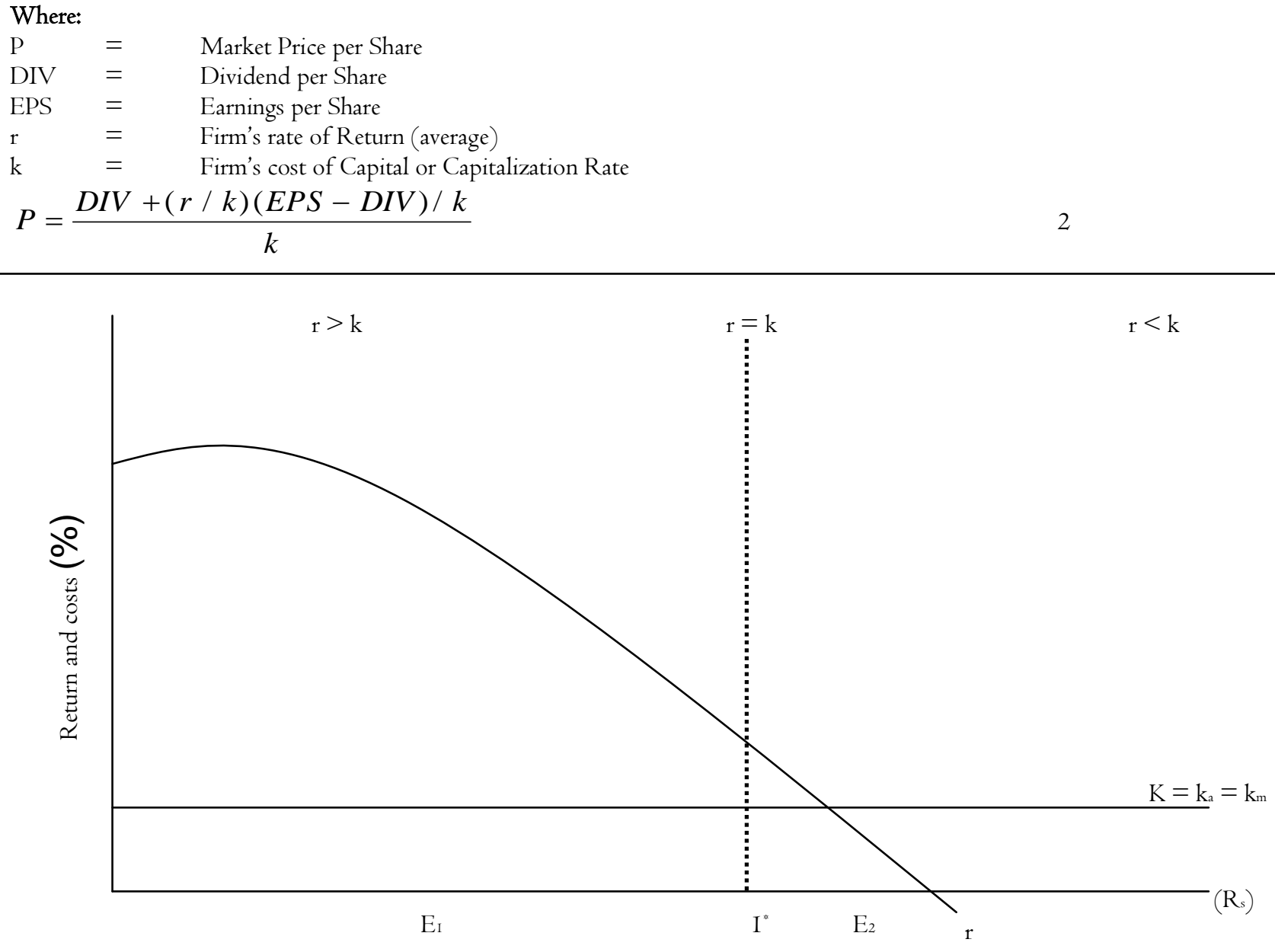

Earning, investment and new financing 


\section{Relevance of Dividend Policy}

The relevance of dividend policy based on future dividend uncertainty Gordon (1962) proposed valuation models that associate the market value of shares with dividend policy. Gordon examined the stock market price and the dividend policy and suggested that the dividend policy should be appropriate.

\section{The Miller-Modigliani (MM) Hypothesis}

According to "Miller and Modigliani (MM), under a perfect market situation, the dividend policy of a firm is irrelevant, as it does not affect the value of the firm.

$$
\begin{aligned}
& r=\frac{\text { Dividends }+ \text { Capital gains (or loss) }}{\text { Share Price }} \\
& r=\frac{D I V_{1}+\left(P_{1}+P_{0}\right)^{n}}{P_{0}} \\
& r=\frac{D I V_{1}+\left(P_{1}+P_{0}\right)^{n}}{P_{0}} \\
& P_{0}=\frac{D I V_{1}+P_{1}}{(1+r)}=\frac{D I V_{1}+P_{1}}{(1+k)} \\
& V=n P_{o}=\frac{n\left(D I V_{1}+P_{1}\right)^{n}}{(1+k)}
\end{aligned}
$$

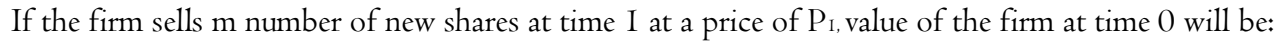

$$
\begin{aligned}
& n P_{0}=\frac{n\left(D I V_{1}+P_{1}\right)+m P_{1}-m P_{1}}{(1+k)} \\
& =\frac{n D I V_{1}+n P_{1}+m P_{1}-m P_{1}}{(1+k)} \\
& =\frac{n D I V_{1}+(n+m) P_{1}-m P_{1}}{(1+k)}
\end{aligned}
$$

MM's valuation Equation (I8) allows for the issue of new shares, unlike Walter's and Gordon's models."

$$
m P_{1}=1_{1}-\left(X_{1}-n D I V_{1}\right)=1_{1}-X_{1}+n D I V_{1}
$$

"By substituting Equation (I9) into Equation (I8), MM showed that the value of the firm is unaffected by its dividend policy, thus:

$$
\begin{aligned}
& =n P_{0}=\frac{n D I V_{1}+(n+m) P_{1}-m P_{1}}{(1+k)} \\
& =\frac{n D I V_{1}+(n+m) P_{1}-\left(I_{1}-X_{1}+n D I V_{1}\right)}{(1+k)}
\end{aligned}
$$




$$
=\frac{(n+m) P_{1}+P_{1}-I_{1}+X_{1}}{(1+k)}
$$

The price of the share at the end of the current fiscal year is determined as follows:

$P_{0}=\frac{D I V_{1}+P_{1}}{(1+k)}$

$P_{1}=P_{0}(1+k)-D I V_{1}$

The value of $\mathrm{P}_{\mathrm{I}}$ when dividend is not paid is:

$P_{I}=R_{s} I O O(I . I 0)-0=R s$ IIO

The value of $\mathrm{P}_{\mathrm{I}}$ when dividend is paid is:

$P_{I}=R_{s} I 00(I . I 0)-R_{s} 5=R_{s} 105 "$

\section{Gordon's Model}

Myron Gordon is developing a very popular model that is directly related to the market value of the company's dividend policy.

$P_{0}=\frac{D I V_{1}}{(1+k)}+\frac{D I V_{2}+}{(1+k)^{2}} \ldots \frac{+D I V_{00}}{(1+k)^{00}} \quad \sum_{t=1}^{00} \frac{D I V_{t}}{(1+k)^{t}}$

$P_{0}=\frac{D I V(1+g)}{(1+k)}+\frac{D I V(1+g)^{2}}{(1+k)^{2}}+\frac{D I V(1+g)^{3}}{(1+k)^{3}}+\ldots+\frac{D I V(1+g)^{n}}{(1+k)^{n}}=\sum_{t=1}^{n} \frac{D I V(1+g)^{t}}{(1+k)^{t}}$

From Equation (4):

$P_{0}=\frac{D I V_{1}}{k-g}$

From Equation 5:

$P_{0}=\frac{E P S_{1}(1-b)}{k-b r}$

"The equation above explicitly shows the relationship of expected earnings per share, EPS ${ }_{1}$, dividend policy as reflected by retention ration, $\beta$, internal profitability, $\mathrm{r}$, and the all-equity firm's cost of capital, $\mathrm{k}$, in the determination of the value of the share. Equation (6) is particularly useful for studying the effects of dividend policy on the value of the share.

$$
P_{0}=\frac{E P S_{1}(1-b)}{k-b r}=\frac{r A(1-b)}{k-b r}
$$

(Since EPS $=\mathrm{rA}, \mathrm{A}=$ assets per share)

If $\mathrm{r}=\mathrm{k}$, then

$P_{0}=\frac{E P S_{1}(1-b)}{k-b r}=\frac{r A(1-b)}{k-b r}=\frac{E P S}{k}=\frac{r A}{r}=A$ 


$$
P_{0}=\frac{r A}{r} \quad(b=0)
$$

If $\mathrm{r}<\mathrm{k}$ then $\mathrm{r} / \mathrm{k}<\mathrm{I}$ and from Equation (9) it follows that $\mathrm{P}_{0}$ is smaller than the firm's investment per share in assets, A. It can be shown that if the value of $\mathrm{b}$ increases, the value of the share continuously falls.

\section{The Bird-In-the-Hand Argument}

According to Gordon's model, dividend policy is irrelevant where $\mathrm{r}=\mathrm{k}$, when all other assumptions are held valid. But when the simplifying assumptions are modified to conform more closely to reality, Gordon concludes that dividend policy does affect the value of a share even when $r=k . "$

$$
\begin{aligned}
& P_{0}=\frac{D I V_{1}}{\left(1+k_{1}\right)}+\frac{D I V_{2}}{\left(1+k_{2}\right)^{2}}+\frac{D I V_{3}}{\left(1+k_{3}\right)^{3}}+\ldots+\frac{D I V_{n}}{\left(1+k_{n}\right)^{n}}=\sum_{t=1}^{n} \frac{D I V_{t}^{t}}{\left(1+k_{t}\right)^{t}} \\
& P_{b}=\frac{D I V_{0}(1+g)^{1}}{\left(1+k_{1}\right)^{1}}+\frac{D I V_{0}(1+g)^{2}}{\left(1+k_{2}\right)^{2}}+\ldots+\frac{D I V_{0}(1+g)^{n}}{\left(1+k_{n}\right)^{n}}=\sum_{t=1}^{n} \frac{D I V_{t}^{t}}{\left(1+k_{t}\right)^{t}}
\end{aligned}
$$

$P_{b}=\frac{D I V_{0}(1+g)}{\left(1+k_{1}\right)^{1}}+\frac{D I V_{0}(1+g)^{2}}{\left(1+k_{2}\right)^{2}}+\ldots+\frac{D I V_{0}(1+g)^{n}}{\left(1+k_{n}\right)^{n}}=\frac{D I V_{1}(1+g)^{n}}{k^{t}-g}=\frac{(1-b) E P S}{k^{t}-b r}$

\section{Empirical Review}

Abor (2008) "discovered that there is a correlation between corporate earnings and dividend payments and concluded that both past and current earnings influence corporate dividend policy." Musa (2009) "examined the impact of dividend policy on stock prices of 53 listed companies in Nigeria using a similar multiple regression model that used five variables: current earnings, previous dividends, cash flow, investments and assets. The study found that five metric variables affect the dividend policy of Nigerian companies."

Abubakhar (2012) "investigated the effect of dividend payout ratios on stock prices of non-listed Nigerian companies in a probabilistic sample of twenty-six companies using multiple regression models. The study found a statistically significant relationship between dividend payments and stock prices. He also discovered that the size of unlisted companies significantly explains Nigerian stock prices. Both the payment of dividends and the size of companies had a positive effect on stock prices. However, the results of the study do not provide sufficient evidence of the insignificance of dividends, as the study did not take into account the impact of profits and dividends on the model."

Adesina, Uwuigbe, Uwuigbe, Asiriuwa and Oriabe (2017) investigated the impact of dividend policy on Nigeria stock price valuation. During ten years (2006-2016), four of the twenty-two banks were analyzed. In their study, they noted that earnings per share have a strong impact on stock prices, while dividend yields and a percentage of stock price stability have a significant impact. However, it was concluded that Nigerian companies need to consider other companies' dividend policies in order to increase their profits and future performance.

Adesola and Okwong (2009) "tested the relevance of Nigeria stock price dividend theories with cross-sectional data from twenty-seven companies over the period 1996-2006. They commented that they have discovered the positive and significant impact of dividends on stock prices. The A-sample activities of Nigerian companies indirectly call into question the empirical validity of the dividend insignificance." Khalid, Chijioke and Aruoriwo (2010) "investigated the effect of dividend yield and dividend payout ratio on changes in UK listed companies' stock prices. A regression model was used to analyze the data, which showed a positive relationship between dividend yield and stock prices and showed that dividend payouts are statistically insignificant."

Amadasun (20II) tried to test the hypothesis that dividend would not increase the price of Nigerian equities using First Bank (Nig) plc as a case study. The study used a regression model that included share price per share as the explanatory variables, earnings per share, return on capital employed, retained earnings, and price-earnings ratio. The results of the study showed a statistically insignificant regression coefficient for both per-share dividend and earnings per share."

Black and Scholes (1974) "examined the impact of dividend policy on the value of companies listed on the New York Stock Exchange. The Capital Asset Pricing Model (CAPM) was used to analyze five-year secondary data (equity and dividend prices) of 25 listed companies. They concluded that corporate dividend policy had no effect on the price of their shares. On the contrary, Aharony and Swary (1980) used a model of naïve expectations of quarterly dividends and earnings and found that stock prices responded to increases in dividend payments while overlapping with earnings announcements. His finding confirms 
the dividend relevance proposal." Budagaga's (2017) study supported the theory of dividend significance after examining the impact of dividend payments on forty-four companies on the Istanbul Stock Exchange over a nine-year period.

Chirima (2015) examined the effect of dividend payment on stock prices of Zimbabwe listed service companies over a five-year period (2008-2012). Data were analyzed by chi-square and regression model. The result showed a statistically significant correlation between dividend announcements and stock prices.

Dada, Malomo, and Ojediran (2015) "support this claim and conclude that investors prefer paying dividends rather than future growth. Iqbal, Ahmed and Shafi (2014) analyzed the effect of the dividend bubble on the stock prices of thirty Karachi listed companies over a period of eleven years. The time series of the thirty listed companies were analyzed using a linear regression model. The result showed that earnings per share, return on equity, holding ratio are positively correlated with share price, while dividend yield and price to earnings ratio have a negative impact on price. activities. However, the study concluded that the dividend has a strong positive impact on KSE stock prices and therefore supports the theory of dividend significance." There are failures in the study resulting from the use of thirty company time series over eleven years. The data obtained by the panel would have been more accurate in reaching its conclusions and conclusions.

DE Angelo and DE Angelo (2006) also found that "dividend content is very relevant. Adefila, Oladipo and Adeoti (2004) studied the impact of dividend policy on the market price of equities. The methodology used was the correlation of the dividend of the Pearson product to the stock price of fifteen companies. The study found that the correlation coefficients are statistically insignificant for most of the fifteen companies. He also found that the correlation between net profit (earnings) and stock prices is statistically insignificant for all the companies analyzed."

Edward (2014), studying the effect of dividends on the stock price of some selected companies on the Ghanaian stock exchange between 2005 and 2009, using descriptive analyzes of primary data, found that dividends are highly correlated actions in Ghana. Ojeme, Mamidu, and Ojo (2015) examined "the impact of dividend policy on the assets of shareholders of listed banks in Nigeria before and after the global financial crash over a four-year period (2007-2010). Secondary data of the 2I banks quoted during this period were obtained from the NSE and from the company's published annual reports. The study concluded that the positive correlation between the average market value of shares and the dividends paid by banks indicates that the payment of dividends is appropriate and that the amount paid affects the market value of banks' shares. This is not valid evidence of the dividend insignificance theory. He used only correlation analysis and four-year data. It did not consider the effect of earnings on stock prices according to the theory of dividend insignificance."

Egbeonu, Edori and Edori (2016) "examined the weighted average of five year financial summary data of twelve listed firms from the various sectors of the Nigerian Stock Exchange in order to measure the impact of dividend policy on firms' value. The study reported that internal rate of return is inversely insignificant, Dividend per share is inversely significant while earning per share is positively significant to share price."

Iftikhar, Raja and Sehran (2017) "established that dividend has a positive statistical influence on stock price after they investigated the impact of dividend policy on five state banks of the Karachi stock Exchange (KSE) for a period often years. They concluded that dividend is relevant in KSE. Budagaga's (2017) study supported the dividend relevance theory after observing the effect of dividend payment on forty-four firms' value of Istanbul Stock Exchange for duration of nine years."

Kanwal (2012) "studied the impact of dividend on stock prices of chemical and Pharmaceutical companies in Pakistan Stock Exchange for the period 200I-2010. Secondary data of five variables: Stock dividend, Earning per Share (EPS), Profit after Tax (PAT), Retention Ratio and Return on Equity (ROE) were analyzed with panel regression model. The study showed that Stock dividend, (EPS), (PAT) are statistically significant. In other words, these variables have positive impact on stock prices while Retention Ratio and Return on Equity have negative impact on share prices. The study asserted that changes in dividend policy provide statistically significant information content which can be used to make predictions about future stock prices, and that the findings support the informational content of dividend hypothesis. These findings' assertions indicate that changes in dividend payment merely create occasions for changes in stock prices and that there was no sufficient evidence to suggest that stock price changes are caused by dividend payments."

Khan (2012) "sampled of twenty-nine companies to explicate the effect of dividend on stock prices for the period 200 I to 20I0. The study used fixed and random effect model on panel data and found that dividend policy has positive effect on share prices after controlling for the effects of earnings per share, profit after tax, and return on equity and concluded that dividend irrelevance theory is not applicable in case of Pakistan Stock Market."

Oduwole (2015) "assessed and compared the predicted power of Nigerian earnings and dividends over fourteen years (200I-20I4). Quarterly data on the used variable (EPS, interim and final dividends) were obtained from the Nigerian stock market. The study used portfolio valuation dimensions (Sharpe index and Jensen alpha) to assess portfolio return on investment based on dividend and return, respectively. The results show that the weighted market capitalization portfolio, which has the highest quarterly dividend yield, outperformed the market and retained policy, while a similar return-based portfolio did not outperform the market. This is not proof of the theory of dividend insignificance."

Ordu, Enekwe and Anyanwaokoro (2014) conducted a study to determine the effect of dividend payments on Nigerian market share prices. During the twelve years (2000-20II), the activities of seventeen listed companies were considered. 
Using the regular Least Squares technique, a positive effect was found between the market share price (MPS) and the stock dividend (DPS). This result supports the theory of the importance of dividends, confirming that an increase in dividends causes a rise in the market share price.

Oyinlola and Ajeigbe (20I4) studied the "impact of dividend policy on stock prices of listed companies in Nigeria using 22 companies listed on the Nigerian stock exchange over the period 2009-2013. He used a panel regression model to determine the effect of per-share dividends and retained earnings on the share price. The results show that both dividends and retained earnings have a significant impact on the share price. In addition, Granger causality tests show that a dividend on a Granger stock causes the stock price."

Ozuomba, Okaro, and Okoye (2013) "conducted a study to assess the impact of dividend policy on Nigerian stateowned shareholders' wealth over a twelve-year period (2000-20II). Secondary data from ten randomly selected two hundred and sixteen public limited companies were analyzed by multiple regression models using dividend per share variable, while earnings per share (EPS) and share price per share (MPS) are independent variables. The results showed that eight companies' EPS and MPS are statistically significant and affect the wealth of listed companies, while the two companies are not statistically significant with a $10 \%$ confidence interval." The research model is wrong because, to reflect the wealth of stockholders, the dividend used the stock variable as a dependent variable instead of the stock price as shown in the target. EPS, DPS, and MPS data are not synchronized. There is also little data to use, as instead of using panel data, he performed analyzes on individual companies' time series and his findings are therefore very misleading.

Rabindra (2012) studied the impact of dividends on Nepal Stock Exchange financial and financial institution stock prices by analyzing secondary data using a regression model. The price of shares is a dependent variable, while the explanatory variables are dividend per share (DPS), retained earnings per share, lagged earnings per share and lagged market price per share. The result showed that the dividend affects stock prices more than retained earnings.

Toby (2014) investigated the importance of dividend policy in determining the price of Nigerian stock market stock by selecting a couple of dozen shares between 2005 and 2012, along with a dividend regression analysis and timing of retained earnings in individual companies. The study found that there is no significant relationship between the change in dividend policy and the change in share price. This surprising result differs from the existing literature on the effect of dividends on stock prices. The result was company-by-company analysis (separate regression analysis for each sample), rather than using panel or crosssectional data to reflect differences between firms. In addition, the study did not include a well-defined income variable in its analysis. Instead, he used retained earnings. The results showed that dividend and retained earnings were not a statistically significant determinant of share price. The study's conclusion that the results are in line with previous research stating that dividend policy is irrelevant in determining the value of the company is therefore highly dubious and invalid.

Udobi, Iyiegbuniwe \& Ezike (2018) "examined the impact of current dividend on market shares prices of the Nigerian Stock Exchange. The study analyzed fifteen years (I5) secondary data of NSE quoted firms with mediation analysis. Stock prices is the dependent variable while current dividend, current earnings, Asset-growth, sales-growth, insider-shareholding and Leverage are the independent variables. The findings indicate that current dividend has a direct (Unique) effect on share price, and at the same time has indirect effect on share price through current earnings. It concluded that current earnings partially mediate the effect of current dividend on quoted Nigerian firms."

Miller and Modigliani (I96I) (M\&M) investigate various issues related to dividend policy. They use a multi-period valuation formula to show the irrelevance of dividend policy to shareholders in a tax-free world. In addition, M\&M derives a company valuation equation that explicitly includes the existence of favorable opportunities for the company (those that earn more than the cost of capital) and associates this growth component with the definition of a commonly used growth company. $\mathrm{M} \& \mathrm{M}$ also analyzes the relationship between stock price increases, earnings per share and dividends paid per share on the amount of foreign and domestic financing, and uses the term "informative content" of dividends. In addition, M\&M claims the concept of customer effect, stating that each company tends to attract a group of shareholders who prefer a particular corporate payment relationship.

Lee (I976) "reviewed the results obtained by Gordon (I959) and Friend and Pucket (I964) and made his crosssectional model general, using the General Functional Form Specification (GFF) for the model. GFF models use data to specify a specific ecological way of studying the impact of dividend yields on stock prices. Lee shows that the choice of the particular ecological form used in the statistical test significantly influences the empirical results. It submits that the most accurate functional form of dividend effects tests is the non-linear form and that the effect of the dividend on stock returns does not differ significantly from the effect of retained earnings."

Black (1976) "examines the contradiction between dividend convenience theories and the actual practices of companies and investors. Theories developed by $\mathrm{M} \& \mathrm{M}$ use restrictive assumptions (such as tax assumptions or different tax treatment of dividends and capital gains) to analytically show that dividend policy is irrelevant. However, almost all successful companies pay dividends and dividend policy is a major concern for financial executives."

Black (1976) continues to study the theoretically derived effects of taxes (in which companies pay little or no dividends) and the informative effects of dividends (an unexpected increase in dividends may indicate a better future for the 
company). Then, consider the different dividend preferences of shareholders over bondholders (bondholders should prefer lower dividends because dividend payments mean they are less active in the event of bankruptcy). But Black goes on to say that shareholders may also prefer lower dividends if they result in lower investment fund raising costs. Irrational beliefs can play a role in claiming an investor's dividend. In addition, the impact of owning high or low dividend shares on the portfolio is simply unknown. Black concludes that we cannot currently prove that dividends matter, but we are not prepared to say that dividends are certainly not important.

Joannos and Filippas (1997) evaluated the dividend payment practices of 34 companies listed on the Athens Stock Exchange between 1972 and 1988 and found that the Greek corporate dividend policy reflected the Lintner model. Current income dividend formation is the most related and important variable that causes a change in dividends, while corporate dividend payment practices and policies are also affected by the previous dividend payment period.

Vasiliou and Eriotis (2003) tested the Lintner model and concluded that there are two ways to improve the original model; For the purpose of treating the change in the dividend between $\mathrm{t}$ and $\mathrm{t}-\mathrm{I}$ as dependent variables and independent variables, the change in the profit of the enterprise between $\mathrm{t}$ and $\mathrm{t}-\mathrm{I}$ and the change in the dividend between $\mathrm{t}-\mathrm{I}$ shall be taken into account. I yacht -2 . Vasiliou and Eriotis believe that Greek companies adopt dividend payments, ie dividend payments, depending on the long-term goal of dividend payments (denoted by the dividend variable delay), which is adjusted accordingly to net income.

Brav et al. (2004) have shown that US corporate executives do not like dividend cuts, but prefer to keep dividends at their current levels. Signal theory assumes that dividend increases can be seen by the administration as a signal that it believes profits are above market consensus. Because management attaches great importance to maintaining dividend levels, an increase in dividends does not mean a sign of short-term profit growth, but rather a level of long-term sustainable profit. If this theory is correct, it should be possible to observe a real improvement in corporate earnings after dividend increases.

Dittmar and Mahrt-Smith (2007) studied "relationships in the US market based on corporate governance index, participation rates and other data on institutional investors and public pension funds, and the market value of cash deposits. Pinkowitz et al. (2007) examined the relationship between corporate governance in 35 countries and the market value of cash holding in these countries. In both cases, the investigation concluded that the introduction of corporate governance had an impact on the value of cash deposits. A factor other than the cost to the institution of influencing the market value of the cash deposit is the actual option value of financial slack." This is due to the fact that economic weakness is of greater value to many companies with growth potential, which are insecure but have difficulty in raising money (Suwabe, 2006).

Pinkowitz and Williamson (2002) showed that the market value of cash holdings in the US market is significantly influenced by the existence of growth opportunities, uncertainty about investment opportunities and good access to capital markets. Deciding on the optimal funding options and dividend policy are some of the most difficult financial decisions. In this context, two capital structure theories (hierarchy theory and substitution theory) are related to the company's dividend policy. Hierarchy theory (hierarchical theory) assumes that entrepreneurs determine the priority sources of capital, not the optimal relationship between liabilities and social capital. Entrepreneurs prefer to finance their activities from internal sources, such as net profit less dividends, depreciation income, and proceeds from the sale of short-term securities and other surplus assets. In cases where debt financing is required, bonds are first issued, followed by new operations (Quan, 2002; Mazur, 2007; McManus et al., 2006).

Nitta (2006) analyzed dividend policy from the perspective of an interactive game between corporate executives and shareholders, looking at the key question of how dividend policy could affect shareholder value. Dividend policy can provide shareholders with information on management's position on earnings trends and current stock prices, as well as their financial position. Asghar et al. (20I I) have shown a positive and significant relationship between price volatility and dividend yield, but after adding control variables, dividend payment and dividend yield are an insignificant relationship and positive with price volatility and an insignificant relationship with income volatility.

Naser et al (2013) "show the bird-in-hand theory and the relevant value theory managers consider to explain dividend policy. External factors related to the economic conditions together with the state of the capital market and lending conditions are all important factors in formulating dividend policy by companies listed on the Abur Dhabi Securities Exchange. The extensive review of dividend policies and the empirical evidence in Husan-Aldin, et al (2010) still conclude that the reason why companies pay dividends, or adopt a particular dividend policy is still a puzzle." The works of Murekefu and Ouma (2012) "sought to establish the relationship between a dividend payout and firm performance among listed firms in the Nairobi Securities Exchange. The results indicated that dividend payout was a major factor affecting firm performance, hence dividend policy is relevant."

Mehta (2012) "attempted to determine empirically the important factors which affect the dividend payout decisions of UAE firms. The study provides evidence that profitability and size are the most important considerations of dividend payout decisions by UAE firms." Arshad et al (2013) "studied the association between dividend payout policy and ownership structure of Karachi Stock Exchange firms over the period 2007-20II. The results did not consistently support the positive association between ownership structure and dividend payout policy and dividend decision." 
Ramadan (2013) "investigates the influence of dividend policy on the share price volatility for Jordanian industrial firms. The experimental results showed that the two components of dividend policy studied, dividend yield and dividend payout, have a significantly inverse correlation with share price volatility." Khan (20I2) "has studied a sample of 29 chemical and pharmaceutical companies listed on the Karachi Stock Exchange for the period 200I-20I0 and found that stock dividend, earnings per share and profit after tax have a significantly positive relationship with stock prices."

Ozuomba et al (2013) "found that the dividend policy of public limited companies influences the wealth of shareholders in Nigeria." Adediran and Alade (2013) "found a significantly positive relationship between dividend policy and profitability in Nigeria."

Illaboya and Aggreh (2013) "examined the relationship between dividend policy and share price volatility in 26 sampled firms listed on the Nigerian Stock Exchange (NSE) for the period 2004 to 20I I. The finding indicates that dividend yield exerts a positive and significant influence on share price volatility while dividend payout exerts a negative and insignificant influence on share price volatility."

Bougatef (20I4) "investigates the impact of dividend payments on common stock prices using a panel data of listed firms in Tunis Stock Exchange for a period of 2000 to 2008. The empirical evidence reveals that Tunisian investors reward firms paying cash dividends."

\section{Methodology}

"This study used quasi experimental research design approach to test the validity of MM hypothesis on irrelevance of dividend policy in Nigeria. This approach combines theoretical consideration (a-prior criterion) with the empirical observation and extract maximum information from the available data. The researcher's aim in this study is to ascertain whether dividend policy is irrelevant in Nigeria as proposed by Miller and Modigliani in I959."

\section{Sources of Data Collection}

The study used for collecting data for this research is the secondary source of data collection obtained from various issues of: (i) Nigerian Stock Exchange (NSE) Annual Reports and Statement of Accounts.

\section{Data Analysis Instrument}

The study employed a "panel data regression analysis. This is because the data set consists of observations of multiple variables over multiple time periods. Thus panel data combines time series and cross sectional data. It allows the researcher the flexibility in modeling differences in behaviour across individuals firm, it is also appropriate for this study because of its ability to take into account heterogeneity problem or individual effects in cross sectional data and give more informative data. The panel regress ion equation is different from a regular time-series or cross section regression by the double subscript attached to each variable. The general form of the panel data model is specified as":

$$
y_{i}, \alpha+\beta X_{i, t}+\varepsilon_{i, t}
$$

The "subscript $i$ denotes the cross-sectional dimension and $t$ represents the time-series dimension. The left-hand variable $y$ represents the dependent variable in the model which represents the value relevance of firms listed on the Nigeria Stock Exchange, $\beta x$ contains the set of explanatory variables in the estimation model, $\alpha$ and is taken to be constant overtime $t$ and specific to the individual cross-sectional unit"

\section{Model Specification}

$$
M V=f(D P R, R R, D Y, D P S)
$$

The regression models are thus formulated as

$$
M V_{1}=\beta_{0}+\beta_{1} D P R_{i}+\beta_{2} R R_{i}+\beta_{3} D Y_{i}+\beta_{4} D P S_{i}+\varepsilon
$$

Where

MV = Market value proxy Tobin Q

$\mathrm{DPR}=$ Dividend payout ratio

$\mathrm{RR}=$ Retention ratio

$\mathrm{DY}=$ Dividend Yield

DPS $=$ Dividend per Share

Method of Estimation and Testing

i. Panel data regression model specifications 
Panel data can be estimated and analyzed in three different specification models. These are the correlation matrices the Fixed Effect Model (FEM) and the Random Effect Model (REM). In this study the fixed effect model is chosen over pooled OLS regression because of the advantages the former has over the latter.

\section{ii. Pooled Regression Model}

Albrigim Zappe and Winston (20II) stipulated that the error term should be independently and normally distributed with zero mean and constant variance and more importantly must not correlated with the independent variables pooled OLS linear regression is given as follows:

$$
Y_{i t}=\beta_{0}+\beta_{1} X_{1 i t}+\beta_{2} X_{2 i t}+\beta_{3} X_{4 i t}+\beta_{4} X_{5 i t}+U_{i t}
$$

where $Y_{\text {it is }}$ the dependent variable; $\beta_{0}$ is a constant term: $\mathrm{X}_{\mathrm{I}}$, to $\mathrm{X}_{5}$, are the independent variables; $\beta_{1}$ to $\beta_{4}$ are slope parameters: $\mathrm{i} . . . \mathrm{n}$ refers to the cross-sectional units and $\mathrm{t}$ is the time period.

\section{ii. The fixed effect model}

The fixed model can be specified as

$$
Y_{i t}=\alpha_{i}+\beta_{1} X_{1 i t}+\beta_{2} X_{i t}+\beta_{3} X_{i t}+\beta_{4} X_{i t}+U_{i t}
$$

Where $\mathrm{i}$ in refers to the cross-sectional units representing the intercept value for each cross-sectional unit.

\section{A-Priori Expectation}

Base on theories such as market efficiency theory and empirical results examined in this study, the variables are expected to have a positive effect on the dependent variables. The mathematical implication is stated as follows:
$\beta_{1}>\beta_{1}>\beta_{1}>\beta_{1}>0$
Reject MM hypothesis
$\beta_{1}<\beta_{1}<\beta_{1}<\beta_{1}>0$
Accept MM hypothesis
$t_{1}>t_{1}>t_{1}>t_{1}>0$
Reject MM hypothesis
$t_{1}<t_{1}>t_{1}>t_{1}>0$
Accept MM hypothesis

\section{Analysis and Discussion of Findings}

The objective of the study as earlier stated was to the validity of MM dividend policy irrelevant hypothesis in among Nigeria quoted manufacturing firms.

Table I Random Effect versus Fixed Effect Models

\begin{tabular}{lccc}
\hline \multicolumn{2}{c}{ Redundant Fixed Effects Tests } & & \\
\hline Effects Test & Statistic & d.f. & Prob. \\
\hline Cross-section F & 2.529902 & $(\mathrm{I} 4,69)$ & 0.0056 \\
\hline Cross-section Chi-square & 36.458539 & I4 & 0.0009 \\
\hline
\end{tabular}

\begin{tabular}{|c|c|c|c|}
\hline Test Summary & $\begin{array}{l}\text { Chi-Sq. } \\
\text { Statistic }\end{array}$ & Chi-Sq. d.f. & Prob. \\
\hline Cross-section random & 3.144965 & 4 & 0.0009 \\
\hline
\end{tabular}

Correlated Random Effects - Hausman Test

\section{Source: computed from E-View output}

The "Hausman test tests the null hypothesis that the coefficients which are estimated by the efficient random effects estimator are the same as the ones estimated by the consistent fixed effects estimator. Therefore, this includes insignificant P-value, Prob $>$ chi2 larger than 0.05, the null is more suitable to use random effects. According to above table shows Hausman specification test the model has the value of $\mathrm{p}=0.0009$ for the regression model of dependent and independent variables. This 
shows fixed effect model is more appropriate, because the null hypothesis is not accepted. Therefore, this includes insignificant P-value, Prob $>$ chi2 larger than 0.05, then it is more suitable to use random effects. However, if we have a significant P-value, then we should use fixed effects models."

\section{Regression Results}

The table below has detail of the regression results for the study.

Table 2: Presentation of Regression Results

\begin{tabular}{|c|c|c|c|c|}
\hline \multicolumn{5}{|l|}{ Fixed Effect Model } \\
\hline Variable & Coefficient & Std. Error & t-Statistic & Prob. \\
\hline DPR & $0.8 \mathrm{I} 8574$ & 3.167067 & 3.276949 & 0.0026 \\
\hline RR & 0.733345 & $4.45 \mathrm{I} 247$ & 2.650678 & 0.0174 \\
\hline DY & 0.800215 & 3.401035 & 4.207544 & 0.0362 \\
\hline DPS & 0.612747 & 3.560265 & $2.87086 \mathrm{I}$ & 0.0356 \\
\hline $\mathrm{C}$ & I0.45667 & 4.374480 & 2.390380 & 0.0196 \\
\hline \multicolumn{5}{|c|}{ Effects Specification } \\
\hline \multicolumn{5}{|c|}{ Cross-section fixed (dummy variables) } \\
\hline R-squared & 0.753232 & Mean dependent var & & 14.35273 \\
\hline Adjusted R-squared & $0.4845 \mathrm{IO}$ & S.D. dependent var & & 4.122745 \\
\hline S.E. of regression & 3.723024 & Akaike info criterion & & 5.655537 \\
\hline Sum squared resid & 956.4025 & Schwarz criterion & & 6.190417 \\
\hline Log likelihood & -229.8436 & Hannan-Quinn criter. & & 5.871027 \\
\hline F-statistic & 2.093574 & Durbin-Watson stat & & 2.362240 \\
\hline Prob(F-statistic) & 0.005125 & & & \\
\hline \multicolumn{5}{|c|}{ Random Effect Model } \\
\hline DPR & 0.619454 & $3.06269 \mathrm{I}$ & 3.310320 & 0.0001 \\
\hline RR & 0.539439 & 5.349744 & 4.792833 & 0.0000 \\
\hline$\overline{D Y}$ & 5.606305 & 2.301002 & 3.055870 & 0.0006 \\
\hline DPS & 0.988076 & $3.35766 \mathrm{I}$ & 1.527497 & 0.1304 \\
\hline $\mathrm{C}$ & II.85007 & 4.179509 & 2.835278 & 0.0057 \\
\hline \multicolumn{5}{|c|}{ Effects Specification } \\
\hline & & & S.D. & Rho \\
\hline Cross-section random & & & 2.038155 & 0.2306 \\
\hline Idiosyncratic random & & & 3.723024 & 0.7694 \\
\hline \multicolumn{5}{|c|}{ Weighted Statistics } \\
\hline R-squared & 0.636903 & Mean dependent var & & 8.647318 \\
\hline Adjusted R-squared & $0.5095 \mathrm{II}$ & S.D. dependent var & & 3.717629 \\
\hline S.E. of regression & 3.706214 & Sum squared resid & & I I40.090 \\
\hline F-statistic & 5.795075 & Durbin-Watson stat & & 2.126371 \\
\hline Prob(F-statistic) & 0.000718 & & & \\
\hline \multicolumn{5}{|c|}{ Unweighted Statistics } \\
\hline R-squared & 0.015568 & Mean dependent var & & 14.35273 \\
\hline Sum squared resid & $\mathrm{I} 455.720$ & Durbin-Watson stat & & $\mathrm{I} .75912 \mathrm{I}$ \\
\hline
\end{tabular}

\section{Source: Computed from E-View output}

\section{Discussion of Findings}

The opinion that dividend policy has effect on the market value of listed companies has long been a point of departure among scholars in the field of finance, what is today known as the dividend puzzle. The Gordons relevant theory was challenged by the Miller and Modigliani irrelevant theory. However, it is important to note that the assumptions of the MM hypotheses are not attainable mostly in the emerging financial market like Nigeria where the financial market cannot be defined as a regulated or deregulated market. Empirical evidence has validated the relevant theory as opposed to the irrelevant theory.

The findings in the sectors above consolidate the opinion of Gordons and invalidate the MM hypotheses. This finding shows that dividend policy is a major determinant of stock prices of the quoted firms. "This finding confirms the findings of Lucky et 
al., (2015) on the effects of dividend policy on the stock prices of Nigeria commercial banks, it confirm the findings of Baskin (2005) on the relationship between dividend policy and stock prices in United States of America. It is in line with the findings of Naziret al (2010) who concluded that share price volatility is significantly correlated to dividend policy; the findings of Suleiman et al., (20II) studied the association of dividend policy with share price volatility in Pakistan and the findings of Hussainey et al(20I I) on the relationship between dividend policies in UK."

\section{Conclusion}

The study used pooled panel data regression analysis to test the irrelevance of MM hypotheses of quoted companies in Nigeria. Data from 20 quoted companies spanning 2008 to 2017 were analyzed. The empirical results obtained from the panel regression analysis show that dividend policy, measured by dividend payout ratio, retention ratio, dividend per share and dividend yield. The study found there is positive and significant impact on the market value of quoted companies on floor of Nigerian stock exchange. It can therefore be concluded that dividend policy is relevant in the valuation of market value. This signifies that managers and policy makers can influence value of quoted firms by variation in dividend policy.

\section{Recommendation}

Based on the findings of the study, the following recommendations are made:

- Quoted companies should manage their dividend policies effectively since it has significant impact on their market value and optimal dividend policy which implies policy of trade-off between dividend payout and retain earnings should be well managed and investors should have adequate knowledge of dividend policy of quoted firms that will correspond with their investment objectives of avoid conflict in dividend policy.

- Management, the regulatory authorities and macroeconomic variables should be properly planned to affect positively dividend policy and the market value of quoted firms and the dividend policy of the quoted firms should be properly defined in such a way that environmental factors would not affect the market of the quoted firms.

- The regulatory bodies should device policies that help create conducive environments that will enhance stock prices of quoted firms and Nigerian capital market and the regulators should make policies that will enhance and advance the operation of the capital market for better dividend policy and stock prices.

- Policies should be made to enhance optimal capital structure of the quoted firms for better dividend policy and positive effect on stock prices and policies should be formulated by the management of the quoted firms and the regulatory authority to manage external forces such as global financial crises that affects the capital market and the stock prices of the quoted firms.

\section{References}

Abdul, A., \& Muhibudeen, L. (2015). Relationship between dividend payout and firms performance: Evaluation of dividend policy of OANDO plc. International Journal of Contemporary Applied Sciences, 2 (6), 56

Abdullahi, A. (20I4).Dividend policy and its impact on stock price: A study on commercial banks listed in Dhaka Stock Exchange. Global disclosure of Economics and Business, 3 (I), 9

Abor, J. (2008). Determinants of capital structure of Ghanaian firms. African Economic Research Consortium Biannual Workshop (AERC) Research paper I76, Nairobi, Kenya.

Abubakhar, S. (2012). Dividend payout ratio and share price movement of listed Non-service firms in Nigeria: Empirical study. www.abu.edu.ng/publications/20I9

Adediran, S. A. And Alade, S.D. (2013). Dividend policy and corporate performance in Nigeria. American Journal of Social and Management Sciences, 4(2), 7I-77.

Adediran,S.A., \& Alade, S.D. (2013). Dividend policy and corporate performance in Nigeria.American Journal of Social and Management Sciences,4(2), $71-77$.

Adefila, J.J., Oladipo, J.A., \& Adeoti, J.O. (2004). The Effect of dividend policy on the market price of shares in Nigeria: Case study of fifteen quoted companies. International Journal of Accounting. Univetsity of Ado-Ekiti, 2 (I), I-IO

Adesina, K., Uwuigbe, U., Uwuigbe, O.R., Asiriuwa, O. \& Oriabe, S. (2017). Dividend policy and share price valuation in Nigerian banks. EuroEconomica, 36(I), I-I

Amadasu, D.E. (201 I).Dividend is relevant: A restatement. African Research Review Journal, 5(4), 60-72

Anil, K., \& Kapoor, S. (2008). Determinants of dividend payout ratios-A study of Indian information technology sector, The International Research Joumal of Finance and Economics, I5(2), 63-71

Arshad, Z. Akram, Y, Amjad, M. \& Usman, M. (2013). Ownership structure and dividend policy, interdisciplinary.Journal of Contemporaty Research in Business, 5(5), 378-40I.

Arslan, I., Farooq, A., \& Ali Raja, S. (20I4). The effect of dividend bubble on share price: Evidence from KSE-30 index. Research Journal of Finance and Accounting, 5(13), 83-87. 
Baker, H.K., \& Weigand, R. (20I4). Corporate dividend policy revisited. Journal of Managerial Finance, 4(2), I26-I44. doi.IO.IIO8/MF-03-20I4-0077.

Bougatef, K. (20I4). How do dividend payments affect stock prices? The Case of Tunisian Firms. The Journal of Commerce, $3(2), 2 I-25$.

Budagaga, A. (2017).Dividend payment and its impact on the value of firms listed on Istanbul Stock Exchange: A residual income approach. International Journal of Economics and Financial Issues, 7(2), 370-376. http.www.econjournals.com

Chirima, D.T. (20I5). The Impact of dividend payments on stock prices in a developing economy: The case study of services firms listed on the Zimbabwe Stock Exchange. Case Studies Journal, 4(5), I26-I33

Dabrowska, J. (2009). Does dividend policy follow the capital structure theory? Managing Global Transitions, 7(4), $367-382$.

De-Angelo, H., \& De-Angelo, L. (2006). The irrelevance of the MM dividend irrelevance theorem. Journal of Financial Economics, 79(2), 293-315.

DeAngelo, H., DeAngelo, L. \& Skinner, D. (2004). Are dividends disappearing? Dividend Concentration and the Consolidation of Earnings. Journal of Financial Economics, 72, 425-456.

Dittmar, A. \& Mahrt-Smith, J. (2007).Corporate governance and the value of cash holdings.Journal of Financial Economics, $83(3), 599-634$.

Edward, A.B. (2014). The Impact of Dividend payment on share prices of some selected listed companies on the Ghana Stock Exchange. International Journal of Humanities and Social Sciences, 4(I), I79-I90

Egbeonu, O.C., Edori, I.S., \& Edori, D.S. (2016). Effect of dividend policy on the value of firms: Empirical study of quoted firms in Nigeria Stock Exchange. Research Journal of Finance and Accounting, 7(3), I7-24

Erasmus, P. \& Scheepers, R. (2008). The relationship between entrepreneurial intensity and shareholder value creation, Managing Global Transitions, 6(3), 229-256.

Fama, E.F. \& H. Babiak (1968). Dividend policy: An empirical model.Journal of American Statistical Association, 63, II32II6I.

Hakeem, S.A., \& Bambale, A.J. (2016).Mediating effect of liquidity on firm performance and dividend payout of listed manufacturing companies in Nigeria. Journal of Economics Development, Management, IT, Finance and Marketing, $8(I), 15-35$.

Huda, F., \& Farah, T. (20II). Determinants of dividend decision: A focus on banking sector in Bangladesh. International Research Journal of Finance and Economics, 77, 33-46

Husan-Aldin, N.A., Rafforty M, \& Pillqar, R. (2010). Dividend policy: A Review of Theories and Empirical Evidence, International Bulletin of Business Administration, 9, I7I-200.

Husan-Aldin, N.A., Rafforty M, and Pillqar, R. (2010). Dividend policy: A review of theories and empirical evidence, International Bulletin of Business Administration, 9, I7I-200.

Iftikhar, A.B., Raja, N.J., \& Sehran, K.N. (2017). Impact of dividend policy on stock prices of firms. International Scientific Journal Theoretical and Applied Science, 3(47), 32-37.

Ilaboya, O. J. \& Aggreh, M. (2013). Dividend policy and share price volatility. Journal of Asian Development Studies, 2(2), I09-122.

Inyiama, O.I., \& Ugah, H. (2015). Interactions between earnings and dividend payout rate in the oil and gas sector: Evidence from Nigeria (2004-20I4). International Journal of Finance and Accounting, 4(5), 253-26I

Iqbal, A., Ahmed, F., \& Shafi, A.R. (20I4). The effect of dividend bubble on share price:Evidence from KSE-30 index. Research Journal of Finance and Accounting, 5(13), 83-87

Iyiegbuniwe,W.I., \& Ezike, J.E.(2018). Empirical analysis of the impact of current dividend policy on share price: Evidence from Nigeria. Unilag Journal of Business, 4(2), I33-I60

Walter, J.E. (I962). Dividend Policy: It's influence on the value of the enterprise. Journal of Finance,I8(2), $280-291$.

Jensen, M.C.\& Meckling, W.H. (I976). Theory of the firm: managerial behaviour, agency costs and ownership structure.Journal of Financial Economics, 3, 305-360.

Kanwal, I.K. (2012). Effects of dividends on stock prices: A case of Chemical and Pharmaceutical Industry of Pakistan. Journal of Management, 2(5), I4I-I48.www.cribfb.com/journal/index.php/amfbr American Finance \& Banking Review

Khalid, H., Chijioke, O.M., \& Aruoriwo, M.C. (2010).Dividend policy and share price volatility: United Kingdom evidence. Journal of Risk Finance, I2(I), 57-68

Khan, K.I. (2012). Effect of dividend on stock prices - A Case of Chemical and Pharmaceutical Industry of Pakistan, Management, 2(5),I4I-I48.

Lintner, J. (1956). Distribution of income of corporations. American Economic Review, 46..97-II3.

Majanga, B.B. (2015). The dividend effect on stock price: An empirical analysis of Malawi listed companies. Accounting and Finance Research Journal,4(3), 99-I05. 
Mazur, K. (2007). The determinants of capital structure choice: Evidence from Polish Companies, International Advances in Economic Research, I3(4), 495-5I4.

McManus, I., Gwilym, O. \& Thomas, S. (2006). Payment history, past returns and the performance of UK zero dividend stocks, Managerial Finance, 32(6), 518-536. Research Journal of Finance and Accounting,5(6), I76-189.

Mehta, A. (2012). An empirical analysis of determinants of dividend policy - evidence from UAE companies, Global Review of Accounting and Finance, 3(I), I8-3I.

Miller, M., \& Modigliani, F. (I96I). Dividend policy, growth and the valuation of shares. Journal of Business, $34(4), 4 I I-433$.

Murekofu, T. M. and Ouma, O.P. (20I2). The relationship between dividend payout and firm performance: A Study of Listed Companies in Kenya, European Scientific Journal, 8(9), I99-215.

Naser, K. Naseibah, R. \& Rashood, W. (2013). Managers' perception of dividend policy: Evidence from companies listed on Abu Dhabi Securities Exchange Issues in Business Management and Economics, I(I), I-I2.

Ojeme, S., Mamidu, A.I., \& Ojo, J.A., (2015).Dividend policy and shareholders' wealth in Nigerian quoted banks. Canadian Social Science Journal, II(I), 24-29.

Ordu, M.M., Enekwe, C.I., \& Anyanwaokoro, M. (20I4).Effect of dividend payment on the market price of shares: A study of quoted firms in Nigeria. IOSR Journal of Economics and Finance, 5(4), $49-62$

Oyinlola, O.M., \& Ajeigbe, K.B. (20I4).The impact of dividend policy on stock prices of quoted firms in Nigerian. International Journal of Economics, Commerce and Management, 2(9), I-I7.

Ozuomba, C.N, Okaro, S.C., \& Okoye P.V.C. (2013). Shareholders value and firm's dividend policy: Evidence from public companies in Nigeria. Journal of Management Sciences, 2(I2), 26-28.

Ozuomba, C.N., Okaro, S.C. and Okoye P.V.C. (2013). Shareholders' value and firms' dividend policy: Evidence from Public Companies in Nigeria. Research Journal of Management Sciences, 2(I2), 26-28.

Preacher, K.J., \& Kelly, K. (20II). Effect size measures for mediation models: Quantitative strategies for communicating indirect effects. Psychological Methods.I6 (I), 93-II5.

Ramadan, I. Z. (2013). Dividend policy and price volatility- Empirical Evidence from Jordan, International Journal of Academic Research in Accounting, Finance and Management Sciences, 3(2), 15-22.

Shrikant, P., \& Yuserrie, Z. (2015). Dividend policy decisions: Theoretical views and relevant issues. Reports on Economics and Finance, $I(I), 43-58$.

Toby, A.J. (2014). Empirical test of the dividend policy irrelevance hypothesis in the Nigerian context. Research Journal of Finance \& Accounting, 5(6), I67-I78.

Udobi, P.I. (2016). An empirical analysis of Miller \& Modigliani dividend policy irrelevance theory: Evidence from the Nigerian Stock Market. Unpublished Ph.D Thesis, Universityof Lagos.

\section{Copyrights}

Copyright for this article is retained by the author(s), with first publication rights granted to the journal. This is an open-access article distributed under the terms and conditions of the Creative Commons Attribution license (http://creativecommons.org/licenses/by/4.0/). 